\title{
COSMOLOGIA, CRISE E PARADOXO: DA IMAGEM DE HOMENS E MULHERES BRANCOS NA TRADIÇÃO XAMÂNICA KUNA
}

Carlo Severi

O vínculo entre os vários tipos de narrativa e a construção de memórias sociais tornou-se óbvio para historiadores, antropólogos e cientistas sociais em geral, com os trabalhos de Paul Ricoeur, dentre outros autores. Se, como Ricoeur argumentou brilhantemente, narrar uma história não é apenas um modo de recordá-la, mas também um meio "para refigurar a nossa própria experiência de tempo" (Ricoeur 1983:9), a narratividade deve ser considerada não somente como um estilo literário particular, mas também como uma forma de existência da própria memória ${ }^{1}$. Com base nessa perspectiva muitos historiadores, assim como alguns psicólogos (White 1973; Bruner 1990), têm sido tentados a argumentar que nenhuma memória é imaginável sem um arcabouço narrativo.

A relação da memória social com as imagens é menos clara. Ao longo de quase toda a sua vida, Aby Warburg (1932) tentou esboçar uma teoria geral da memória social baseada tanto em imagens quanto em textos. A ênfase que ele colocou nas relações complexas entre símbolos visuais e significado, na necessidade de considerar uma pintura ou um objeto esculpido como um mero elemento em uma série de representações que devem envolver necessariamente ações rituais, textos, tradições orais ou até simples imagens mentais, bem como sua visão a respeito da análise da memória social como um meio para estudar a vida social dos símbolos, certamente são passos decisivos que apontam na direção de uma nova abordagem dessa questão.

Entretanto, as idéias de Warburg sobre a memória social foram pouco exploradas desde a sua morte e, pelo menos no campo da antropologia social, ainda há muito por fazer para que seja possível compreender como uma tradição cultural pode basear-se em imagens ${ }^{2}$.

Um terceiro problema envolvido no tema deste artigo refere-se à representação da experiência traumática. A análise do trauma como um fenômeno que afeta a percepção e a memória, e como um processo psi- 
cológico que gera sintomas dolorosos, foi obviamente um dos primeiros passos para a descoberta do inconsciente por Freud. Todavia, como Freud apontou desde logo em sua obra, o trauma não provoca apenas reminiscências dolorosas. Ele pode colocar em perigo a própria memória, enquanto processo estreitamente relacionado com a construção (e a sobrevivência) do Ego. Nesses casos, nenhuma história sobre a experiência traumática pode ser contada, uma espécie de lacuna, ou uma imagem enigmática, aparece à consciência como um substituto complexo e persistentemente enganoso da reminiscência (Freud 1965[1917]:275). Assim, qualquer tentativa de reconstrução de uma representação narrativa do passado (seja ela fiel ou não) tem que lidar com imagens desse tipo.

O ponto crucial aqui é precisamente a relação entre imagem e narração. De um ponto de vista metapsicológico, a emergência dessas imagens como traços mnêmicos parece substituir, se não mesmo evitar, a narração da reminiscência. Como resultantes de um processo psicológico, elas parecem ser mais efetivas que a linguagem, uma vez que registram alguns aspectos da recordação em situações nas quais nenhuma palavra pode ser dita. Entretanto, o fato de elas testemunharem algumas elaborações psicológicas da reminiscência, não significa que revelem meramente a verdade dos fatos recordados. Essas imagens impedem justamente a transformação da experiência subjetiva do tempo em uma "narração" ("récit") que é, segundo Ricoeur, uma das etapas decisivas para a formação da memória (Ricoeur 1985:9).

Que essas representações devem ser tratadas como traços mnêmicos e não como representações precisas, foi uma das primeiras descobertas atribuídas à teoria psicanalítica dos sintomas. Desde então (a saber, desde a sua famosa refutação da "teoria da sedução"), como Freud escreveu magistralmente, a realidade psicológica interna deve ser diferenciada dos fatos históricos externos.

Contudo, a mesma "realidade psicológica" que Freud opôs aos fatos externos, em seus primeiros anos de pesquisa, foi reconhecida por ele, em seus estudos posteriores, como uma das forças mais poderosas atuando na vida das sociedades. A relação entre a obra de Freud e a pesquisa antropológica deste século não foi fácil, com poucas exceções ${ }^{3}$. Nenhuma tradução direta das teorias psicanalíticas no campo dos fenômenos culturais provou ser de fato frutífera, e não poderíamos negar que, nesse contexto, muitas questões permanecem sem respostas, e muitos problemas, insolúveis. Entretanto, seria igualmente difícil negar que algo muito semelhante aos "traços sociais mnêmicos" — relacionados também com a tarefa de representar o trauma e de testemunhar uma complexidade similar — 
é encontrado em práticas normalmente associadas à memória social. As práticas rituais, em particular, são situações nas quais a representação de experiências traumáticas extremas, por vezes tão difíceis na vida cotidiana, pode ser efetivamente expressa e, desse modo, inscrita - através de mecanismos ainda inexplorados — na memória de uma sociedade.

A questão é: como a recordação de uma crise coletiva, de um trauma social, pode ser inscrita na memória de uma sociedade? Como uma tradição ritual pode representar o trauma social como uma experiência? Para discutir este ponto, vou abordar uma transformação relativamente recente da tradição xamânica dos índios Kuna do Panamá: a invenção de um espírito representando, em termos sobrenaturais, a interferência do mais poderoso dos inimigos tradicionais da sociedade kuna, o Homem Branco.

A história do encontro entre o Homem Branco e os Kuna foi brilhantemente resumida por James Howe (1997): "habitando uma região de grande importância estratégica, os Kuna viram-se enredados em esquemas e guerras de outros povos, tentando negociar com ou aliar-se a um dos lados sem abrir mão de sua independência. Repetidamente missionarizados e subjugados, a cada vez rebelaram-se e libertaram-se, até mesmo no século XX" (Howe 1997:85). Desde o começo do século XVI, os Kuna resistiram bravamente às diversas tentativas de colonização. Muitas histórias da tradição oral kuna falam dos episódios notáveis dessa sucessão de agressões externas, tentativas de controle de seus territórios e insurreições contra os espanhóis, os escoceses e, mais recentemente, a polícia panamenha. Para dar uma idéia da intensidade da tragédia kuna, Howe escreve que "durante a última metade do século XVIII quando, [...] depois de aproximadamente três séculos de guerra, a paz finalmente chegou a Darien [...], a guerra e as epidemias tinham reduzido a população indígena pela metade, a cinco mil pessoas aproximadamente" (Howe 1997:89).

Devemos mencionar que, depois de um século de relativa calma, outros Brancos (garimpeiros, comerciantes, missionários e autoridades do novo Estado do Panamá) tentaram controlar o território kuna. Os Kuna, mais uma vez, resistiram a essa invasão e contra-atacaram, até o Tratado que sucedeu o conflito armado de 1925 contra as forças panamenhas. Este Tratado garante até hoje aos Kuna sua precária, e arduamente conquistada, autonomia política, e representa para os índios, dado o contexto histórico, uma notável conquista. Entretanto, não se deve esquecer que os índios americanos, particularmente os da América Central, têm convivido com o Homem Branco há vários séculos. Mesmo quando, como no caso kuna, eles têm sido capazes de rechaçar efetivamente um contato físico destrutivo, os índios ainda sustentam que a presença hoje inevitá- 
vel do Homem Branco dilacerou seu mundo, perturbando o equilíbrio de forças que o regula. Sejam quais forem as transformações não diretamente produzidas pelas repetidas expedições militares, espanholas ou outras, elas estão ligadas agora a essa certeza obsessiva e profundamente enraizada de que algo se rompeu. A memória desse passado traumático, durante o qual a sociedade kuna correu seriamente o risco de desaparecer, permanece viva e pode ser expressa de modo inequívoco e direto; como no discurso do chefe kuna Leonidas Valdés, proferido em 1922, sobre o Descobrimento da América:

\footnotetext{
"Quando os europeus chegaram aqui - disse o chefe - eles abusaram de nós, como vocês estão vendo. Eles espancaram nossos avós, eles mataram nossos avós, eles violaram nossas avós, como vocês estão escutando. Eles chegaram aqui e mataram nossos sábios. Agora, então, eles dizem: celebrem esse dia... eles estão vindo para celebrar o dia da morte dos nossos avôs e avós. Agora, então, nós estamos sentados aqui... Nós nos sentamos aqui sentindo nossa dor" (Salvador 1997:101).
}

Veremos que, na tradição xamânica, a recordação desse passado e o sentimento dessa dor podem ser expressos de modo mais indireto, embora igualmente tocante, por meio da criação de imagens rituais.

O grande antropólogo sueco E. Nordenskiöld, durante sua expedição de 1927 entre os Kuna, coletou muitos objetos interessantes, agora incluídos nas preciosas coleções do Museu Etnológico de Gotemburgo. Entre esses objetos existe uma série de estatuetas, esculpidas em paude-balsa, que representam os "espíritos auxiliares". Essas imagens, usadas pelos especialistas kuna na recitação de cantos dedicados à terapia de várias enfermidades, representam freqüentemente pássaros, tartarugas-marinhas e outros animais. Às vezes, elas possuem uma vaga forma antropomórfica, representando alguns dos seres sobrenaturais da mitologia kuna (Figura 1). Assim como em outras tradições indígenas americanas, essas imagens são evocadas e solicitadas a ajudar durante rituais de cura. Entretanto, algumas dessas figuras kuna são mais surpreendentes (Figuras 2 e 3), pois representam pessoas usando camisa, calça, chapéu e até gravata. Resta pouca dúvida de que, mesmo sendo utilizadas pelos xamãs como espíritos auxiliares nas suas viagens sobrenaturais, elas representam o Homem Branco.

Essa representação do Branco como um espírito auxiliar do xamã kuna (confirmada por várias fontes recentes ${ }^{4}$, incluindo meu próprio trabalho de campo) é surpreendente, e tem sido analisada de diversos 
Figura 1. Alguns exemplos de estatuetas representando os "ajudantes" ou espíritos auxiliares do xamã kuna.
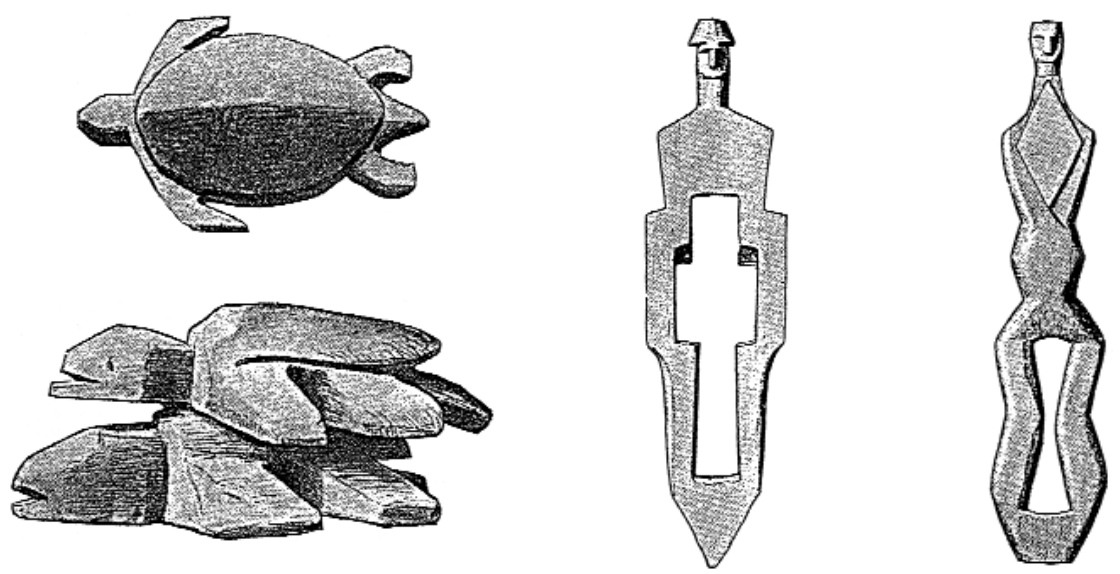

modos. M. Taussig, por exemplo, identificou entusiasticamente nessas estatuetas uma espécie de vingança simbólica da sociedade kuna contra os invasores Brancos. Essa interpretação, que pode parecer surpreendente à primeira vista, é na verdade muito comum, sendo freqüentemente aplicada a outras situações de contato cultural. Manipulando a imagem do Branco, argumenta Taussig, o xamã kuna torna-se simbolicamente capaz de capturar o poder dos seus antagonistas, exatamente como o sacerdote vodu, ou um possuído Songhay, que "captura o poder" de um padre católico ou de um administrador francês tomando sua imagem e, assim, tornando-se "similar a ele" (Métraux 1958; Stoller 1984; 1989)5 Usando a imagem de um Inimigo paradigmático em um contexto de "magia simpática", Taussig argumenta que os Kuna encontraram um modo de assimilá-la. Isto, certamente, é verdadeiro, e meu próprio trabalho sobre o canto devotado à terapia daquilo que os Kuna chamam de "loucura" pode confirmar esse ponto (Severi 1993).

Os problemas surgem quando Taussig atribui à tradição xamânica a intenção de expressar o fato de que "o eu não está mais separado do seu Outro, pois agora o eu está inscrito no Outro do qual ele necessita para definir, por contraste, a si mesmo" (Taussig 1993:252). Taussig conclui, reconhecendo nessas estatuetas kuna (e em particular nas imagens que eu analisei em um artigo sobre o ritual kuna de representação da dor [Severi 1987]) a ilustração "daquilo que tem sido chamado de condição 
Figura 2. Estatuetas representando os espíritos auxiliares do xamã kuna como homens e mulheres brancos.
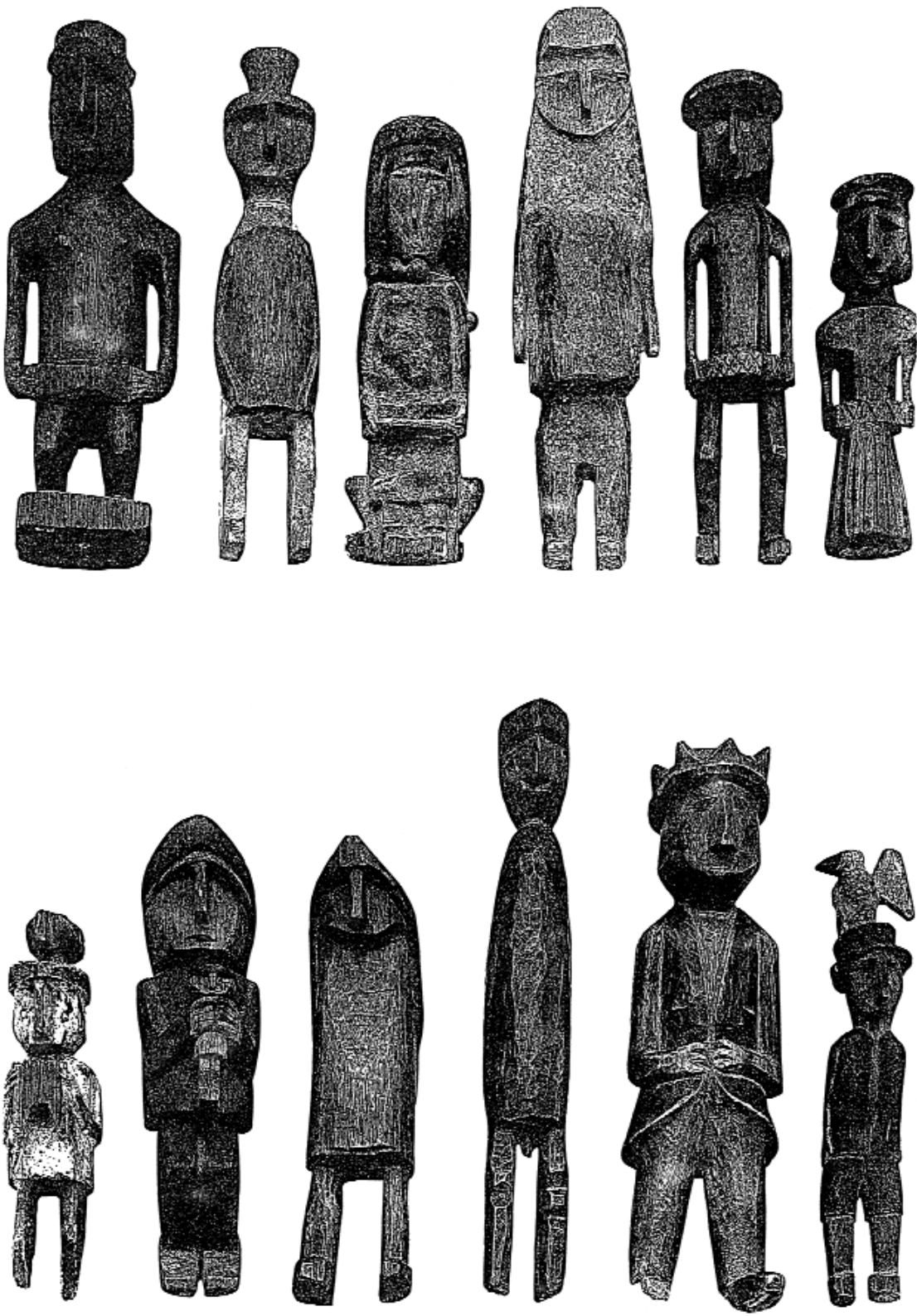
pós-moderna, o reino virtualmente indisputável da cadeia-imagem no capitalismo tardio onde a mercantilização da natureza, tanto quanto a reprodução mecânica e uterina, se vincula a uma variedade de modos de simulação e consumo de poder" (Taussig 1993:251).

Taussig apresenta sua interpretação como parte de uma reflexão sobre as idéias de Benjamin a respeito da mimésis e sobre o que ele chama de "história fabulosa dos sentidos" (Taussig 1993:252). Sua análise não se propõe a ser parte de uma "velha antropologia", supostamente "próxima ao fim", como ele alega repetidamente (Taussig 1993:238), e que, de qualquer maneira, já "teria inevitavelmente perdido o fulcro da questão". Entretanto, sua interpretação de que a representação do Homem Branco é um simples ato de magia simpática, simplifica demasiadamente os fatos kuna. No contexto nativo, o Homem Branco não é apenas um símbolo de poder; ele simboliza, igual e simultaneamente, ansiedade, incerteza, sofrimento mental e até mesmo loucura (Severi 1981; 1993). A tradição kuna representa os Brancos não apenas como poderosos videntes vindos de fora para se tornarem auxiliares mágicos do xamã na sua tentativa de curar várias doenças, mas também como demônios terríveis que aparecem apenas nos sonhos (Severi 1993). Como veremos detalhadamente aqui, a ambivalência dessas imagens, sua representação paradoxal dos valores positivos e negativos atribuídos a alguns seres sobrenaturais, é constitutiva da sua natureza. A contradição é o próprio modo de existência dessas imagens.

Taussig tem razão ao enfatizar o caráter irônico e até mesmo cômico dessas estatuetas. Contudo, está claro que nós não temos aqui um "retrato" jocoso e cotidiano dos Homens Brancos, do mesmo tipo estudado por Keith Basso (1979) entre os Apache ocidentais. Essa representação é ritual e, portanto, é parte constitutiva de um contexto religioso. Essas estatuetas não representam simplesmente o "povo Branco", elas retratam os Brancos como transformados em seres sobrenaturais kuna.

É óbvio que essas representações estão ligadas, de certo modo, à memória dos conflitos históricos entre Índios e Brancos. Entretanto, historiadores e antropólogos tiveram dificuldade em compreendê-las nesses termos, devido a duas razões principais: enquanto seu uso ritual como "auxiliares" nos rituais terapêuticos é evidente (e, posteriormente, iremos descrever detalhadamente seu uso), elas não parecem estar claramente conectadas a narrativas relacionadas aos conflitos históricos com os Brancos. O ponto crucial, todavia, é que essas imagens parecem ser definidas em termos contraditórios. Vistos a partir da perspectiva kuna, os Brancos são concebidos tanto como "videntes" (nelekan), que supos- 
Figuras 3. Estatuetas representando os espíritos auxiliares do xamã kuna como homens e mulheres brancos.
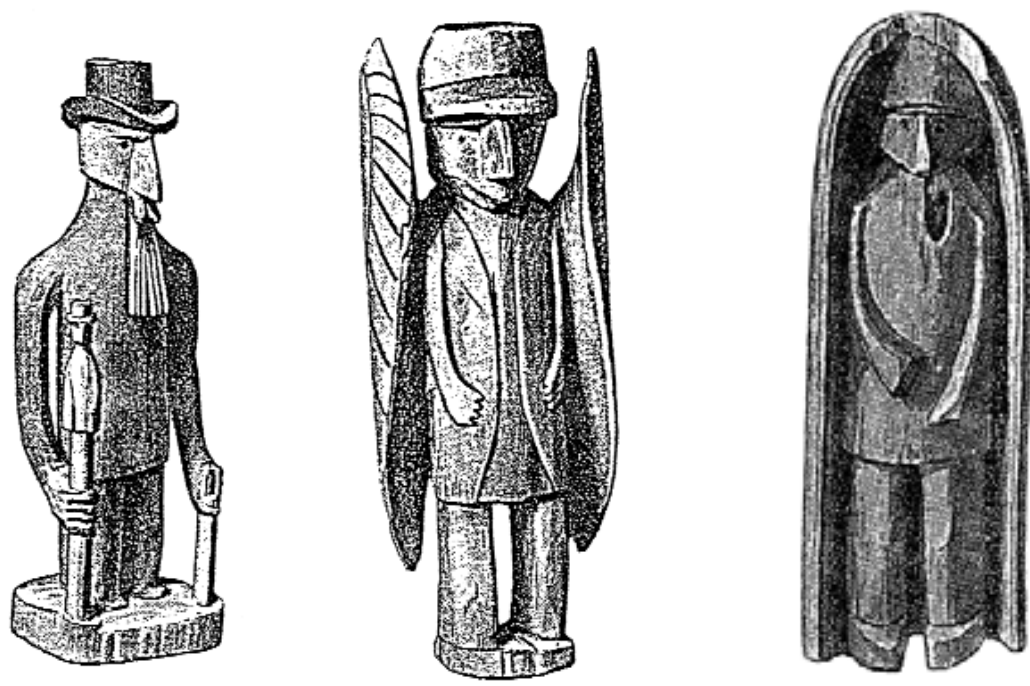

tamente auxiliam a cura xamânica, quanto como espíritos animais patogênicos (nias), que atacam os homens e as mulheres kuna e os deixam doentes. Em conseqüência disso, a tentação de considerar essas representações como "espúrias", "marginais" ou "anedóticas" tem sido forte. $\mathrm{Na}$ verdade, imagens desse tipo foram com freqüência consideradas sintomas de uma decadência das tradições indígenas ou até mesmo signo de submissão simbólica à "mudança cultural" (ou seja, dominação) provocada pelos Brancos. Em outras palavras, considera-se que esse tipo de representação aponta na direção da "modernização": um processo que implica esquecimento social e a perda da identidade étnica indígena.

Eu gostaria de mostrar que essa interpretação das estatuetas kuna é profundamente enganosa, do mesmo modo como é ilusório ver nelas representantes de um espírito pós-moderno consciente, como Taussig tentou fazer. Uma vez reconstruído seu contexto, essas imagens paradoxais podem ser vistas, inversamente, como um exemplo daquilo que Aby Warburg chamou de "engramas de memória social" : o resultado de um processo de lembrança ritual no qual podemos seguir, quase passo a passo, o modo pelo qual uma tradição xamânica consegue simbolizar uma situação de crise. 


\section{O espírito do branco kuna6}

Atualmente, na tradição xamânica kuna, o Espírito do Branco aparece como um ser perigoso, que ataca as pessoas à noite, enquanto elas sonham, e as transforma em locos (loucos). Os Kuna narram a história dessa locura (loucura) da seguinte forma: quando os seres humanos, homens ou mulheres, são tomados pela loucura, emitem o chamado de caça do jaguar, cantam a canção de um pássaro, rolam no chão como cobras, exibem seus órgãos sexuais como fazem os macacos. Aqueles que são acometidos pelo primeiro acesso de loucura se despem inesperadamente do seu status de seres humanos. De fato, para os Kuna, tanto esse acesso de loucura, quanto o delírio concomitante, são sempre signos da presença de um discurso animal em um corpo de Índio.

Por trás dessa imagem de delírio, incansavelmente repetida, como um estereótipo, existem duas histórias oníricas. Uma se refere a um sonho de caça; a outra, a um sonho de copulação. O sonho de caça é um sonho diurno que é sonhado com os olhos abertos. Conta-se que quando um caçador se embrenha na floresta e ouve o som de um pássaro sem ser capaz de avistá-lo, e imediatamente depois disso se dá conta do furioso grunhido de um porco-do-mato sem vê-lo nem rastreá-lo, ou do uivo de um macaco invisível, percebe que mesmo que fique astuciosamente à espreita ou de tocaia, jamais será capaz de ficar cara a cara com esses animais. Ele sabe que essa sucessão característica de gritos de animais, que é acompanhada subitamente por um angustiante senso de ausência, anuncia a vinda do jaguar celeste. Suspenso na extensão mais longínqua do céu, o jaguar celeste não pode ser visto quando desce para caçar na floresta. Sendo um animal mutante e um espírito essencialmente invisível, assume provisoriamente a aparência de outros animais. Mas isso não significa que ele vai esconder-se sob o aspecto visual desses animais pele do porco-do-mato, chifres de um cervo em movimento rápido, penas vermelhas de uma arara. A única coisa que ele pode fazer é ajustar sua voz aos gritos deles, emitir seus chamados de caça ou balançar as folhas das árvores como os macacos fazem quando escapam do caçador. Ele nunca chegará a ser visto.

Conseqüentemente, o canto de loucura entoado pelos xamãs envia o jaguar celeste para a aldeia da escuridão. Em meio às tempestades que assolam constantemente esse lugar noturno ele é visto saindo em perseguição à sua presa. Mas nem aqui ele é totalmente ele mesmo: ora é um pássaro que soa como um jaguar, ora é um jaguar que soa como um pássaro. 
Porém, esse ser mítico não é apenas um caçador de animais. Ele é também, e sobretudo, um caçador de seres humanos. E é aí que entra a segunda história onírica, o sonho de copulação. Invisível à luz do dia, o jaguar aparece em certos sonhos sob a forma de imagem. Ele descarta, então, a imagem de temível caçador para assumir a aparência igualmente perigosa de um parceiro sexual intensamente desejável. Aquele (homem ou mulher) que o vir em seu sono vai se apaixonar por essa visão para sempre e enlouquecerá por causa dela. Analisei em outro trabalho o Canto kuna do Demônio e a concepção complexa de loucura que ele envolve (Severi 1993). Vou enfatizar aqui um único ponto: o Branco é, no Canto do Demônio, identificado como uma das manifestações do jaguar celeste, portanto, ele é não um ser humano, mas um animal perigoso, mesmo que sua aparência possa ser humana. Entretanto, em vez de caracterizá-lo meramente em termos negativos (como uma espécie de monstro de contos de fadas, e uma constante ameaça aos seres humanos), o texto qualifica esse espírito de modo mais complexo e ambivalente. O Espírito do Branco é chamado, na linguagem cerimonial dos cantos, um pilator: "habitante da aldeia dos espíritos". No vocabulário do xamã essa palavra designa uma categoria que associa as pessoas que foram assassinadas (ou suicidaram-se) com aquelas que cometeram assassinatos. O Espírito do Branco, assim, aparece representado simultaneamente como um agressor e como uma vítima.

Essa ambigüidade na representação do Branco não é anedótica nem isolada. Pelo contrário, ela parece estar ligada à representação do mundo sobrenatural em muitas cosmologias indígenas americanas. É um fato recorrente que a representação do Branco se torna ambígua no momento em que, na memória social, o Homem Branco deixa de ser percebido e tratado como uma pessoa de verdade (um guerreiro, um comerciante etc.) e passa a ser representado como um espírito ${ }^{7}$. Vou, portanto, considerar seriamente essa representação kuna do Branco por meio de pares de termos contraditórios, e tentar compreender seu fundamento cultural.

Vimos que o Espírito do Branco é ritualmente definido, nos cantos xamânicos kuna, como um "habitante" de uma "aldeia" invisível, situada na Terra dos Mortos. De fato, essa transferência da representação do inimigo branco do mundo "real" para a terra habitada pelos mortos é crucial na cosmologia kuna. Meu ponto de partida será os dois traços característicos mínimos que parecem definir o Branco (ser "habitante de uma aldeia sobrenatural", e estar relacionado aos mortos), e evocam em detalhes a maneira pela qual a tradição kuna representa esse mundo sobrenatural e define a natureza de um espírito. 


\section{Paisagens kuna: os vivos e os mortos 8}

"Olhe lá: a aldeia de transformações aparece. Aqui os espíritos são transformados em seres de todo tipo, aqui eles nascem, aqui eles rejuvenecem, ... aqui eles podem ficar como nós". Estas palavras, ditas pelo chefe dos espíritos auxiliares do xamã no Canto do Demônio (Gomez e Severi 1983:158-159, 220-225)9 , dão uma primeira descrição nítida do mundo sobrenatural tal como concebido na tradição xamânica kuna. Espíritos e seres sobrenaturais, em geral, vivem em aldeias "invisíveis". Estas aldeias - uma vez me explicou um famoso especialista kuna - "são lugares na floresta estranhos e difíceis de serem vistos, em forma de montículos de pedras. Eles ocultam o chão cheio de fendas e buracos. Através desses buracos os espíritos ascendem à camada superficial da terra. Basta tocar uma aldeia desse tipo para morrer imediatamente" 10.

De fato, muitas dessas aldeias estão enterradas debaixo da terra, na floresta. Mas outras estão situadas no céu, ou escondidas nas profundezas do oceano. Todas elas são lugares muito perigosos. Pessoas comuns não podem percebê-las, pelo menos durante sua vida. Elas podem apenas tomar uma vaga consciência da sua presença ameaçadora. Somente os videntes e xamã ${ }^{11}$ podem realmente ver essas aldeias quando, absorvidos em suas visões ou recitando um canto, eles viajam "além do horizonte". Na descrição dada pelos cantos xamânicos, essas aldeias estão situadas "muito longe", geralmente para o leste. A fórmula freqüentemente usada para mencioná-las é "lá onde a canoa do sol surge", como em outra passagem do Canto do Demônio onde elas aparecem no horizonte, "no mar aberto":

“1. Na distância, lá onde a canoa do sol surge, a aldeia do mar aparece

2. O Velho Pau-de-Balsa, o vidente ${ }^{12}$ olha para a aldeia

3. A aldeia é vista flutuando em mar aberto

4. Na distância, a aldeia-que-surge afunda ligeiramente no mar

5. Nas profundezas do mar a aldeia afunda ligeiramente, a aldeia reaparece na superfície

6. Conquistada pelas ondas, a aldeia surge ligeiramente, a aldeia afunda ligeiramente nas águas

7. O Velho Pau-de-Balsa, o vidente, olha para lá à distância, para o topo da aldeia

8. O Velho Pau-de-Balsa, o vidente, olha à distância, lá onde a canoa do sol surge

9. Uma grande bruma cobre o lugar, lá onde a canoa do sol surge 
10. O Velho Pau-de-Balsa, o vidente, olha à distância, lá onde a canoa do sol aparece" (Gomez e Severi 1983:29-31).

Essas "aldeias" também costumam ser descritas como a "casa" 13 de um número de seres sobrenaturais, como jaguares voadores, animais sem patas ou horríveis tubarões. Sem contradição aparente, todavia, diz-se que essas aldeias sobrenaturais também estão "muito próximas" às aldeias onde vivem homens e mulheres. Os espíritos que as habitam, como foi dito na primeira passagem citada do Canto do Demônio, podem facilmente assumir uma aparência humana e ir viver entre os seres humanos. Um aspecto crucial do seu poder de metamorfose é que eles podem, a qualquer momento, tomar uma aparência humana.

De fato, a paisagem sobrenatural kuna não é descrita apenas como um mundo que aguarda todo ser humano depois da morte. Ela é concebida, também, como uma dimensão invisível sempre imanente (embora de difícil percepção) na vida cotidiana. Qualquer manifestação séria de dor, qualquer infortúnio, qualquer doença, abre suas portas. Um tema central na tradição kuna é que o mundo "dos espíritos", embora invisível, nunca pode ser esquecido. Ele está aqui tanto quanto lá: tão presente e próximo aos seres humanos como uma paisagem verdadeira.

Hoje em dia, muitos Kuna vivem em pequenas ilhas de origem coral, localizadas no arquipélago Kuna Yala ao longo da costa atlântica do Panamá. Essas ilhas habitadas, ligadas à costa por uma longa ponte de toras, são freqüentemente planas e áridas. O horizonte é demarcado de um lado pelo oceano e do outro pela floresta Darien. A agricultura e a caça são os principais meios de subsistência e são realizadas apenas na floresta do continente. A pesca começou a ser praticada recentemente, em geral na área interna ao recife de corais que protege as ilhas habitadas do Atlântico e torna as águas rasas em torno delas particularmente calmas e navegáveis. Com freqüência densamente povoadas, as aldeias são compostas por amplas cabanas de bambu, umas próximas às outras, abrigando a família extensa uxorilocal kuna. Como descrevem os próprios Kuna, essa organização espacial, típica de todo o arquipélago, é dividida rigidamente entre os Vivos, os Mortos, os Animais e as Grandes Árvores. Assim, o mundo parece estar distribuído horizontalmente (de norte a sul e de leste a oeste) entre esses quatro grupos.

O continente é o lugar da agricultura, da caça e da água fresca; as ilhas, que não possuem normalmente fontes de água, são os lugares onde a vida social e os rituais ocorrem. No continente em frente à ilha, na foz do rio que fornece água fresca, existe uma clareira incomum na floresta. 
Ali se situa a Aldeia dos Mortos. Assim, os mortos habitam o mesmo território que os espíritos animais que são a fonte constante de doença e morte. Em alguns casos, as próprias pessoas mortas podem se tornar espíritos. De fato, não há lugar na tradição kuna para o conceito de morte natural. As pessoas morrem porque são atacadas por um espírito hostil; elas são sempre vítimas de vingança ou de um erro fatal. A floresta é um lugar difícil e perigoso; ela esconde (como sabemos) as "aldeias" habitadas por espíritos que atacam os homens que se arriscam em suas redondezas. Esses espíritos matam tais homens, tornam-nos loucos ou doentes. Uma aldeia desse tipo pode materializar-se em um rochedo projetado no oceano, sob um bosque de espinhos ou em um pântano (Prestan 1975:168). Mas a "aldeia espiritual" mais familiar (aquela que é conhecida por todos) é o cemitério, a "aldeia" construída para celebrar os rituais funerários. Permitam-me descrever brevemente dois desses rituais.

Na sociedade kuna, quando um adulto ou pessoa idosa morre, o cadáver é vestido com as melhores roupas do morto e colocado em uma rede com a cabeça voltada "para o nascente", o leste. Uma corda de algodão é posta nas mãos do morto "para ajudá-lo" a atravessar os rios subterrâneos durante sua jornada para o céu. A corda, diz-se, "servirá como uma ponte". O cadáver é então coberto por um pano branco e um longo canto funerário, o Serkan Ikala, é cantado ${ }^{14}$. No dia seguinte, a família do morto vai para a Aldeia dos Mortos, logo ao amanhecer. Depois que a procissão de canoas alcança a foz do rio, o cadáver é colocado em uma cabana sem paredes e enterrado. Algumas oferendas de comida cozida e folhas de bananeira são deixadas sobre o corpo. O cadáver então é coberto com terra que é batida com pás e cozida com a chama de um brazeiro - que será mantido permanentemente aceso pelos parentes - até formar uma camada compacta e homogênea. Feixes de penas multicoloridas pendem dos postes de pau-de-balsa que sustentam o teto da cabana, as quais acompanham o cadáver na sua perigosa viagem para o céu, reino derradeiro dos mortos. Para facilitar essa viagem, os vivos também constroem pequenas escadas de bambu e um pequeno barco que contém as armas de caça que o homem ou mulher mortos necessitarão para sua defesa.

Ao modo da aldeia que o representa, o reino dos mortos é uma réplica exata do mundo dos vivos, com uma exceção: lá, além da luz ofuscante do sol, tudo é dourado — os Kuna dizem que o dourado é a cor do reino dos mortos. O que é invisível aqui, "brilha como ouro" lá.

Ao pôr-do-sol, os participantes do ritual voltam para a ilha, onde todos partilham uma refeição e, então, tomam um banho coletivo de purificação. Dois procedimentos rituais devem ser cumpridos antes que eles 
deixem a Aldeia dos Mortos. Primeiro, algumas sementes de pimenta vermelha, misturadas com água, são colocadas sobre o túmulo. Diz-se que quando a água alcança o corpo sepultado, a pessoa morta abre imediatamente os olhos, e começa a viagem: primeiro para baixo, através das oito camadas ctônicas da terra, e depois em direção ao céu. Concomitantemente, os participantes do ritual irão esticar uma corda (evocando aquela que foi colocada no túmulo) de um lado ao outro do rio mais próximo, e depois cortá-la. A separação final da pessoa morta, e das perigosas "aldeias" que ela terá que visitar, é realizada e explicitamente simbolizada por esse ato de cortar a corda. A jornada da pessoa morta começa, e o ritual está terminado ${ }^{15}$.

Quando uma criança morre, o ritual é muito mais simples. O corpo é enterrado em terra habitada, no interior da cabana da família, debaixo da rede na qual a criança dormia. Os Kuna dizem que esse tipo de sepultamento ajudará a família a ter outra criança. O cadáver de uma criança ainda traz a semente masculina, que o fará germinar como uma planta. Assim, enquanto a proximidade a um cadáver de adulto é fortemente evitada, o contato próximo com o de uma criança fertiliza o terreno árido (usualmente estéril) habitado pelos vivos. Esse sepultamento in loco introduz uma segunda divisão no espaço kuna a partir de um eixo vertical: do topo do céu para as profundezas do mundo subterrâneo. Aqui, inesperadamente, o "mundo dourado" não está mais situado no céu. Tornou-se, em vez disso, um lugar subterrâneo, e é descrito em O Caminho de $\mathrm{Mu}$ (o canto dedicado à terapia do parto difícil ${ }^{16}$ ), como a "camada da terra puramente dourada".

O mundo subterrâneo kuna é composto por oito camadas. Os quatro níveis superiores são o lugar de origem e o esconderijo dos espíritos malignos que trazem as doenças, os nias. No fundo da quarta camada está a fonte do "rio dourado", que leva às camadas mais profundas da terra. É através dessas regiões que a alma de um índio morto deve viajar para alcançar a oitava e mais profunda camada, a morada do Velho Paude-Balsa, o Vidente e, só então, subir ao céu ${ }^{17}$. Ao enterrar a criança debaixo da rede na qual ela sempre dormiu, os índios esperam impedir que sua "alma" tenha que entrar no mundo perigoso dos espíritos, pelo qual a alma doente do Índio deve sempre viajar após a morte. Na verdade, embora a primeira camada subterrânea seja potencialmente hostil, ela é concebida como fértil e povoada, semelhante ao continente do outro lado da ilha. O sepultamento nesse lugar transforma o corpo da criança em uma planta que pode frutificar e retornar para o útero de uma mulher como um "fruto germinante": 
"Por um longo período de tempo os frutos cresceram em você, seus frutos estão todos vermelhos.

Por um longo período de tempo o pássaro vermelho Nalukukule entrou nos seus frutos" (apud Holmer e Wassen 1953:164-165),

diz o xamã no canto dedicado ao parto difícil. Em outra passagem memorável do mesmo texto, a mãe é descrita então como uma "mulherárvore bem enraizada":

“Na camada dourada da terra a raiz sustenta seu tronco: tão profundamente como a camada dourada, sua raiz está fincada solidamente [na terra];

[...] [sua raiz vai] tão distante quanto a camada dourada [da terra], sua raiz transforma [tudo] em ouro puro [...].

Um por um, os animais sobem nos seus galhos manchados, cada um dos seus galhos manchados emite sumos, que pingam com sangue [...].

Quando o vento norte sopra, quando [...] ele sopra através de você,

Seus galhos curvam-se e inclinam-se com o vento; abatidos pelo vento seus ramos emitem um som agudo como os cabos no barco prateado do homem branco" (apud Holmer e Wassen 1953:183-187) ${ }^{18}$.

O simbolismo desses dois rituais (e a concepção subjacente de morte) é particularmente complexo, e não podemos examiná-lo detalhadamente aqui. Todavia, resta pouca dúvida de que, apesar das diferenças, ambos os ritos, o dedicado à criança e o dedicado ao adulto, são construídos a partir da mesma analogia entre o corpo humano e o mundo sobrenatural. Por meio do sepultamento embaixo da sua rede, o corpo da criança transforma-se em fruto, e conseqüentemente a mãe transforma-se em uma árvore cósmica que traz em si um "fruto germinante".

O outro ritual, dedicado aos adultos, é construído a partir da mesma base simbólica. Se nós considerarmos a seqüência crucial de ações que caracteriza o sepultamento de um adulto (a cobertura do corpo com um pano branco, a corda primeiro dada e então cortada, a oferenda de folhas de bananeira depositadas sobre o corpo antes do sepultamento), concluímos que a terra que vai cobrir (ou talvez "envolver") o cadáver da pessoa morta é transformada gradualmente no corpo de uma Mãe originária. Uma série de indicações aponta nessa direção. Vimos que o cadáver "recebe" uma corda de algodão e é então coberto com um pano branco. Na linguagem simbólica dos cantos esse "pano branco" (colocado sobre o cadáver logo após sua morte) sempre designa a vagina. Aqui estão dois exemplos extraídos do Mu Ikala: 
"Do meio do pano branco da mulher um ser humano desce" (apud Holmer e Wassen 1953:90).

"O pano branco secreto dela desabrocha como uma flor" (apud Holmer e Wassen 1953:432).

Deve-se notar que no mesmo texto o sexo feminino pode "expandirse" e se tornar literalmente o sexo da Terra:

"O corpo doente da mulher repousa enfraquecido

Quando os espíritos iluminam o caminho de $\mathrm{Mu}^{19}$, exudações jorram, como sangue

Suas exudações escorrem para baixo da sua rede, tudo como sangue, tudo vermelho

O pano branco interior estende-se para o seio da terra $[\ldots]$

No seio da terra suas exudações reúnem-se em gotas, tudo como sangue, tudo vermelho" (apud Holmer e Wassen 1953:86-92).

O outro objeto simbólico usado no ritual, a corda dada ao morto "para ser usada como uma ponte" para atravessar os rios do mundo ctônico, é sempre comparado nos cantos (e de fato assimilado) a um cordão umbilical (Gomez e Severi 1983:145 e 149; ver, também, infra) ${ }^{20}$. O "corte" definitivo dessa corda, que no final do ritual marca a separação entre a pessoa morta e os vivos, pode então ser interpretado como um retorno ao corpo da mãe, ou mesmo como o renascimento de uma pessoa depois da morte. Uma alusão clara a esse renascimento como um filho ou filha da Mãe Terra é a folha de bananeira (ou banana) deixada sobre o corpo no local do sepultamento. A folha de bananeira (em si mesma uma metáfora para o sexo feminino) é, de um ponto de vista mitológico, precisamente, o lugar onde os primeiros seres humanos nasceram, e ainda hoje é usada para colocar o bebê depois do nascimento. A última parte do Caminho de $\mathrm{Mu}$ é reveladora desse ponto:

“No seio da terra a criança está descendo

No seio da pálida folha de bananeira a criança está descendo

Ela avermelha toda a folha de bananeira" (apud Holmer e Wassen 1953:640$642)^{21}$.

Todas essas indicações são reunidas com clareza em um belo mito recolhido por Prestan e dedicado à origem dos rios: 
“Nos tempos antigos, nosso Pai começou a pensar: 'o que vou fazer?' E então o Pai pensou em fazer a Mãe menstruar. Ele fez isso abrindo o sexo dela com uma faca. Desse modo, quando a Mãe começou a menstruar, os rios e riachos apareceram sobre a terra. Então o Pai fez uma folha de bananeira usando o púbis da Mãe para o recém-nascido se sentar. Por essa razão, as mulheres nas ilhas kuna sempre colocam o recém-nascido sobre uma folha de bananeira" (apud Prestan 1975:230).

De fato, essa dupla referência a um corpo cosmológico e a um universo corpóreo é constitutiva da tradição xamânica kuna: se a Terra pode possuir um sexo feminino, pode-se considerar que o corpo de uma mulher contém "oito camadas" (Kantule e Nordenskiöld 1938), como a terra, ou mesmo "redemoinhos" (Velasquez 1992:702 e ss.), como o oceano. Como mostra a descrição de Chapin das terapias medicinais, um xamã kuna pode identificar em um "sol interior" a garganta de um homem doente, ou uma "dor vindo da sexta camada subterrânea" (Chapin 1983:216-217). Em outros estudos dedicados à tradição xamânica, tentei mostrar que essa representação do mundo sobrenatural nos cantos kuna está associada particularmente à representação da dor (Severi 1987; 1982). Os cantos dedicados à terapia das doenças descrevem sempre a jornada da alma através do mundo invisível dos espíritos como uma metáfora da experiência vivida pela pessoa doente. Portanto, a jornada xamânica descreve primariamente aquele estado de perceber sem ver, que é o sentimento de dor (ver Severi 1987:81-84). Nesse contexto, o sofrimento é descrito simultaneamente em termos cosmológicos e fisiológicos: sofrer é experimentar uma transformação do universo que envolve uma debilitação dramática da balança natural entre o que é visto e o que é percebido pelos outros sentidos. A dimensão fisiológica é descrita como um “corpo interior" que nenhuma percepção visual pode alcançar, e a dimensão cosmológica como um mundo inacessível à percepção normal. Dessa perspectiva, as propriedades do mundo invisível (como os "rios germinantes" do mito que citamos) referem-se ao corpo humano, e as propriedades invisíveis do corpo (por exemplo, a dor gerada pelo trabalho de parto no Caminho de $\mathrm{Mu}$ ) ao mundo exterior.

De acordo com esse princípio, e em virtude da sua segunda visão ou do seu conhecimento dos cantos, o xamã kuna vê a presença escondida dos espíritos no corpo de uma pessoa doente para além do que é visível no mundo. Ele é capaz de interpretar os signos da dor porque está familiarizado com um tipo particular de paisagem: o teatro interior do corpo humano, constituído por "aldeias invisíveis" onde os espíritos vivem. Se 
nos remetemos ao canto que acompanha a pessoa morta na sua jornada, o Serkan Ikala (Holmer e Wassen 1963), descobrimos que não apenas as experiências traumáticas, mas a própria morte são extraordinariamente descritas nesses termos cosmológicos/fisiológicos. Para explicar por que os "olhos do homem que está morrendo perdem a cor" (Holmer e Wassen 1963:35 e ss.), e para descrever o processo pelo qual o corpo se torna progressivamente frio, o texto diz:

54. O espírito da doença deixa um vento entrar no seu corpo

55. Os espíritos do Crocodilo, o Vidente

56. Em seu corpo eles deixam um vento entrar (apud Holmer e Wassen 1963: 54-56).

Posteriormente, esse vento se torna um rio que, literalmente, penetra no corpo:

130. Além do rio, eles chamam os espíritos-femininos que trazem o frio

131. Eles chamam agora os espíritos femininos das nuvens negras

132. E agora o rio está penetrando no seu corpo.

Podemos então esboçar uma primeira conclusão. Do ponto de vista da tradição kuna, as coisas "invisíveis" podem estar simultaneamente "lá" (na floresta, nas profundezas do oceano, no céu) e "aqui" (entre nós, na aldeia povoada) porque elas estão dentro de nós: essas paisagens invisíveis se situam dentro do corpo humano.

Voltemos agora para a paisagem e para o contraste entre o visível e o invisível. Nós vimos que o universo kuna é concebido como um denso mosaico de territórios diferenciados e antagônicos, partilhados pelos vivos, pelos mortos, pelos espíritos dos animais, vegetais e rochas. O mapa cosmológico traçado por E. Nordenskiöld, o pioneiro dos estudos kuna, ilustra claramente essa visão da ordem cosmológica (Figura 4).

Nessa imagem, o estado do cosmos kuna aparece claramente descrito: o mundo subterrâneo, com suas "aldeias" habitadas pelos espíritos camadas após camadas, parece ser uma representação ordenada da organização do universo mitológico. Seres humanos pertencem à terra, espíritos ao mundo ctônico. De modo a alcançar o céu, a alma da pessoa morta tem que atravessar, camada após camada, o mundo subterrâneo ${ }^{22}$. De fato, na mitologia kuna um ser é definido pelo território ao qual ele pertence. Isto se aplica particularmente à distinção entre seres humanos e não-humanos. Enquanto nossa cultura parece estabelecer uma conti- 
Figura 4. A estrutura do universo kuna de acordo com E. Nordenskiöld (1938). A camada superficial (A) está oposta ao mundo ctônico (B). A letra S marca a jornada do Sol na abóbada celeste.

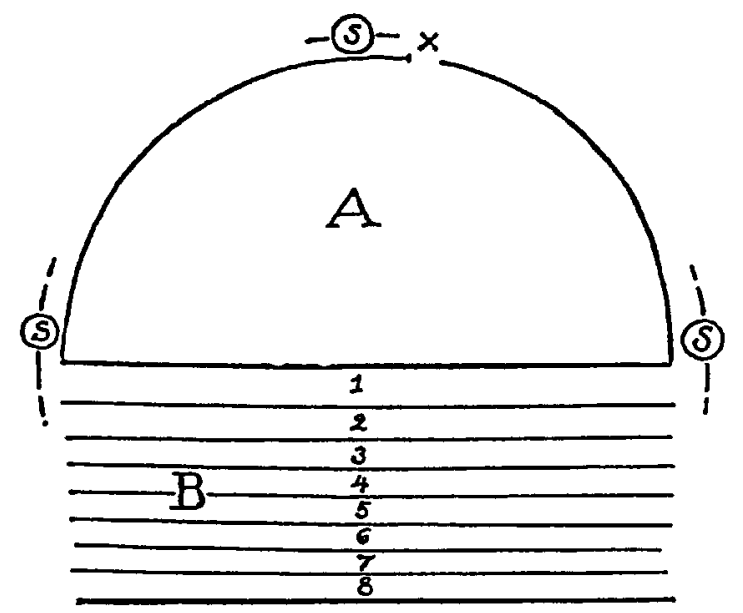

nuidade entre os reinos humano, animal, vegetal e mineral, em termos de uma natureza corpórea homogênea ${ }^{23}$, para os índios a situação física dos seres parece estar mais marcada por uma irremediável descontinuidade. No mundo kuna cada ser tem seu território, e o padrão de organização desses territórios se assemelha antes a um arquipélago composto por ilhas separadas do que a uma estrutura única organizada em linhas hierárquicas. Por outro lado, lá onde o pensamento ocidental estabelece uma descontinuidade radical entre o homem e o mundo exterior, ou seja, no plano espiritual (ou, nas versões modernas da mesma idéia, nos planos lingüístico e psicológico), os índios vêem apenas continuidade e troca contínua (realizada, por exemplo, pela realização de rituais). No pensamento indígena, essa continuidade sempre leva à representação do reino da natureza como uma cultura ${ }^{24}$. De acordo com os Kuna, os animais casam entre si segundo seus próprios costumes; eles constroem suas aldeias na floresta; e falam sua própria língua. Nem a vida social organizada nem mesmo o fato de falar uma língua (e atribuir a isso o status de uma forma de conhecimento) pode dar ao índio um lugar privilegiado no mundo. O que dá a qualquer ser sua própria especificidade é, do ponto de vista kuna, seu território: o espaço ao qual ele pertence no universo. 
Todavia, uma vez que abandonamos esse ponto de vista externo (que é aqui o ponto de vista do antropólogo), e entramos nas paisagens sobrenaturais descritas em detalhes pelos cantos e desenhos kuna, distinções precisas entre categorias de seres tornam-se menos claras, e o que poderíamos chamar de ambigüidades ontológicas aparecem por toda parte. $\mathrm{O}$ que surge, então, é a representação de um espaço complexo e até mesmo contraditório, no qual seres sobrenaturais, longe de serem definidos exclusivamente pelo território que ocupam no universo, podem pertencer simultaneamente a diferentes níveis ontológicos. Isto ocorre no simbolismo dos rituais e cantos funerários, nos quais posições "no mundo" e "no corpo" podem ser simultâneas. Esse aspecto, entretanto, é muito mais desenvolvido na tradição kuna e vai além da analogia estabelecida entre o corpo e o mundo.

Vimos que a paisagem sobrenatural kuna é organizada de acordo com dois eixos: um eixo vertical (céu/mundo subterrâneo) e um eixo horizontal que reflete, em termos metafísicos, a oposição entre a ilha e o continente. Entretanto, em todas as fontes tradicionais kuna que temos estudado, ambos os limites do mundo, horizontal e vertical, designam a dimensão na qual os espíritos vivem. Os dois eixos terra/céu e ilha/floresta parecem ser equivalentes, e até mesmo intercambiáveis: em muitos casos, aquilo que "está voltado para o Leste" também está situado no mundo subterrâneo. No Caminho de $M u$, assim como em outros cantos xamânicos, considera-se que o espírito vive tanto no "interior da terra" quanto "além do horizonte". No Canto do Demônio, quando os espíritos do xamã estão se preparando para sua busca da alma perdida, eles perscrutam "além dos pontos cardeais", enxergando, por meio disso, o mundo subterrâneo dos espíritos. Os dois eixos do espaço cosmológico, horizontal e vertical, vivem lado a lado e complementam-se nessa representação da paisagem sobrenatural. Aqui encontramos um aspecto da concepção indígena de espaço que nem o esquema cosmológico de Nordenskiöld - com suas distinções úteis mas limitadas, entre diferentes "partes" do mundo - nem a analogia simbólica entre "mundo" e "corpo" podem ajudar-nos a compreender. Como é concebível que "alguns" aspectos do mundo estejam situados simultaneamente em diferentes pontos do universo, além do horizonte e no mundo subterrâneo? Que tipo de ser pode habitar essa dimensão ontológica ambígua? Qual é o significado, se existe algum, dessa dupla localização espacial? Antes de tentarmos responder a estas questões, vejamos mais alguns exemplos dessas duplas localizações, expressas aparentemente em termos meramente geográficos. 
Durante uma conversa com o antropólogo venezuelano R. Velasquez, o chefe e xamã kuna Odis Navas ao sublinhar a importância da quinta camada sob a terra, lembrou que

"o céu está debaixo, depois das oito camadas da terra" (apud Velasquez 1992:719-720),

e de fato a passagem pictográfica do Canto do Demônio que eu coletei confirma e ilustra esse ponto. Vemos aqui uma paisagem acompanhada da sua imagem invertida (Figura 5).

De maneira análoga, o Serkan Ikala afirma claramente que as nuvens podem ser encontradas "no interior da terra":

1. Vocês... nuvens

2. Vocês obscureceram novamente o interior da terra

3. Vocês videntes, eu falo com vocês

4. Vocês nuvens negras

5. Vocês cobriram novamente o lado interior da terra ${ }^{25}$.

De fato, mesmo que nenhuma correspondência entre o corpo e o cosmos esteja em jogo nesse contexto, deve-se lembrar que essas indicações espaciais (de acordo com o princípio de que todo ser é definido pelo território ao qual pertence) são sempre remetidas à definição da natureza de

Figura 5. Concepção invertida da Terra tal como ilustrada por uma passagem da versão pictográfica do Canto do Demônio.

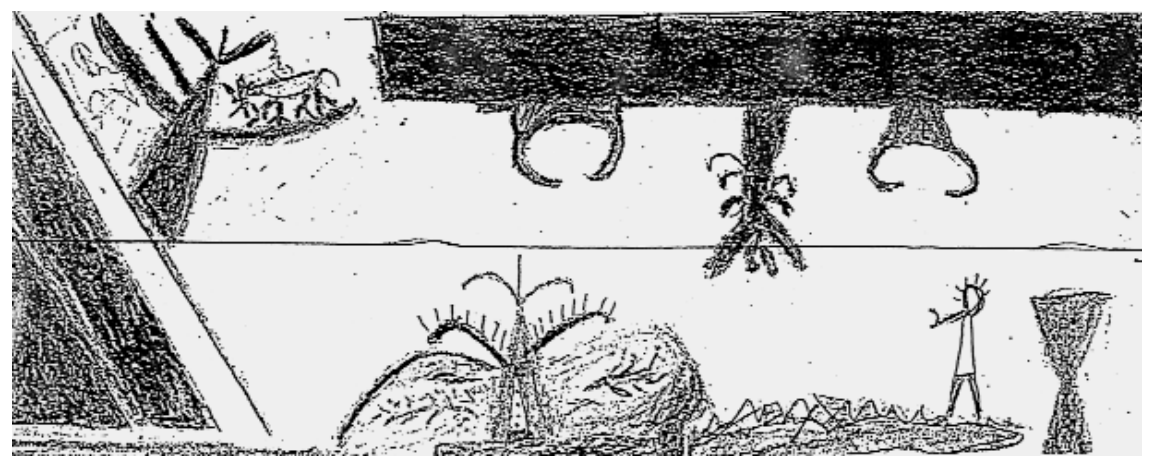


um espírito. "O céu está depois das oito camadas ctônicas da terra" não significa que o céu está "abaixo de nós". Isto quer dizer que o céu está também abaixo de nós, ou, melhor, que um céu invisível está sob a terra. No mundo real, nuvens, ventos e rios não estão em todo lugar. Somente no mundo habitado pelos espíritos essas situações podem ocorrer.

Nos textos xamânicos, considera-se sempre que os espíritos estão simultaneamente "aqui" e "lá". Vimos que, segundo a tradição kuna, foi somente um imperativo mítico proferido no começo dos tempos, que fez com que a sociedade humana se separasse - e mesmo assim apenas na contingência do tempo e não em sua essência - dos animais, das árvores e do mundo mineral. Os princípios fundamentais da vida podem passar continuamente de um corpo para o outro, seja ele humano, animal ou vegetal. Daí o universo estar constantemente sendo ameaçado pela promiscuidade excessiva dos seres e pela desordem que poderia resultar da mistura entre eles. Para entender isso, é preciso compreender o processo de metamorfose que domina esse mundo. Todo ser que mora lá é dotado de uma dupla natureza, e está sempre prestes a sofrer uma transformação. Veremos que, uma vez que a representação do Espírito do Branco está incluída nesse universo, ele seguirá um destino similar de "dupla metamorfose".

Evoquemos, então, outros exemplos do uso de referências espaciais contraditórias e simultâneas em uma única paisagem e vejamos como a descrição de uma paisagem se relaciona com a definição da natureza de um espírito.

\section{Espíritos, imagens e vozes}

Vimos que o Espírito do Branco pode ser representado como um espírito auxiliar. Referindo-se a uma estatueta que representa Balsa, o Vidente, o chefe de todos os espíritos auxiliares de um xamã, um especialista disse a R. Velasquez: "você vê lá a imagem do vidente. Ela está aqui. Mas seu espírito não está aqui. Ele está longe, nas profundezas da terra" (Velasquez 1992:735). A partir de uma perspectiva ocidental, essa afirmação pode parecer óbvia: a imagem de um espírito, tenderíamos a pensar, simplesmente não é em si o próprio espírito.

A estatueta representada, por exemplo, na Figura 6 é apenas a forma visível de um "ser" que está localizado alhures. É desnecessário dizer que essa interpretação é totalmente enganosa. O comentário xamânico kuna está fundamentado em uma perspectiva inteiramente diferente. $\mathrm{O}$ 
Figura 6. Uma estatueta representando um Nele kuna (um "vidente" atuando como um espírito auxiliar nos cantos kuna) (Nordenskiöld 1938).

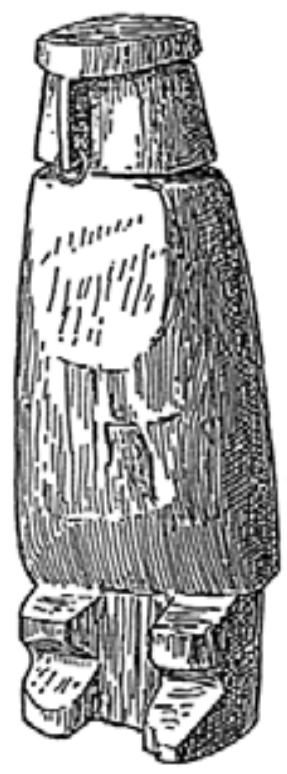

que conta em uma representação como essa, não é sua forma (grosseiramente) humana. O aspecto importante dela é a matéria a partir da qual é feita: o próprio pau-de-balsa. De acordo com a perspectiva xamânica, essa madeira associa a aparência visual de uma árvore poderosa à extraordinária leveza das asas de um pássaro. Veremos que essa conjunção de elementos contraditórios revela a natureza de Pau-de Balsa, o Vidente, de um modo muito mais claro que a sua forma. Assim, a parte secreta do Canto do Demônio descreve o nascimento mítico de Pau-deBalsa, o Vidente:

"Nesse caminho a Árvore de Balsa nasceu. Na fonte do rio chamado Maekanti, no começo dos tempos, apenas animais existiam. Eles eram como pessoas humanas, e eles viviam no rio. Os porcos, os porcos-do-mato e os outros animais eram como seres humanos. O Pai olhava tudo ao redor. Seres malignos estavam por toda parte.

Os nias, os espíritos animais malignos, já estavam lá muito antes do Pai. O Pai chegou depois deles. Ele percebeu que o mundo não poderia ficar daquela maneira, e enviou o próprio filho, que veio com o objetivo de ajudar 
as pessoas. Naquele tempo, os espíritos malignos, os nias, estavam em toda parte, eles eram cegos ou sem pernas. O Pai então tocou seu pênis, e o esperma saiu. Em oito dias, o esperma, reunido em uma taça, solidificou-se, e tomou a forma de um ovo de bacurau ${ }^{26}$. Oito dias depois, o ovo quebrou, produzindo um som semelhante ao canto do bacurau: 'tuu'. Um homem saiu, e o Pai disse: 'meu filho chegou, agora eu vejo que meu grande filho chegou'. E o Pai pensou, e depois ele disse: 'Mas eu ainda não tenho uma esposa?' E o Pai então trabalhou as montanhas ${ }^{27}$ e viu à distância as grandes aldeias invisíveis. E foi assim que o Pai orientou seu jovem filho: 'você nasceu de mim, o grande Pai. Você vai trabalhar para mim'. Essas foram as palavras que o Pai dirigiu a Balsa, o Tronco Leve. Então o Pai abarcou nas suas roupas todas as aldeias invisíveis, e [o filho?] aprendeu a conhecer todas as coisas situadas na terra, exatamente como se ele tivesse contribuído para construí-las. O Pai disse a Tronco Leve: 'Você será o chefe de todos os nuchu$\operatorname{mar}^{28}$. Posteriormente você obedecerá às ordens dadas pelo xamã: você fará o que ele lhe disser, e evitará aquilo que ele proibir'" 29.

O texto acima descreve o "nascimento" do vidente a partir de uma seqüência de extraordinárias metamorfoses. Seu ser parece resultar de uma série de transgressões do modo "normal" de geração de seres. Balsa nasceu de uma taça de esperma sem qualquer intervenção de uma mãe, o filho de um pai solitário. Então, a taça de esperma tornou-se magicamente um ovo de bacurau. Este pássaro é interessante nesse contexto por duas razões: ele só se torna visível durante o pôr-do-sol, entre os domínios do dia e da noite, e ele possui um canto que os Kuna relacionam explicitamente aos gritos de um louco. Do ovo desse pássaro quase humano, Balsa nasceu como um homem. Imediatamente depois disso, entretanto, o texto refere-se a ele como uma árvore. De um ponto de vista cosmológico, então, o nascimento de Pau-de-Balsa é descrito como a presença simultânea de um ser que aparece em três territórios separados e diferentes: os domínios das árvores, dos pássaros e dos humanos. Ele não é nem um pássaro, nem uma árvore, nem um homem jovem. Ele é supostamente todos os três simultaneamente. Sua natureza é ser múltiplo.

Encontramos essa mesma configuração desenvolvida explicitamente em uma outra parte desse canto, na qual a Aldeia de Metamorfoses é descrita.

248. Aqui os espíritos são transformados em seres de todo tipo, aqui eles nascem 
diz o canto para anunciar o surgimento dessa aldeia (Gomez e Severi 1983:linha 248), significando que transformação e nascimento, para um espírito, são a mesma coisa. Refiro-me à fórmula verbal pela qual os textos descrevem esse processo de transformação. Nas linhas 250-251, esse processo de nascimento e metamorfose diz respeito, por exemplo, aos porcos-do-mato:

250. Aqui os nias são transformados em porcos-do-mato, os porcos-do-mato estão lá com suas roupas negras, eles gritam "ya-ya-ya"

251. Os porcos-do-mato estão agora mudados em nias, eles estão transformados em nias, os nias estão transformados

O texto descreve aqui o nascimento de um nia (o espírito animal maligno) por meio de dois movimentos lógicos distintos: primeiro, o espírito invisível é transformado em um animal, o que quer dizer que ele toma a forma visual de um animal; depois, no verso seguinte, a relação é invertida, e o texto afirma que os animais, em contrapartida, estão agora transformados em espíritos. Esse movimento dual de espírito para animal e de animal para espírito só é possível através de duas operações. Quando a presença invisível do espírito é substituída pela aparência de um animal, os porcos-do-mato (como todos os outros animais mencionados na Aldeia de Transformações: vaga-lumes, borboletas, cobras, cervos etc.) usam "roupas negras" e emitem seu grito de caça. Temos, assim, uma seqüência do seguinte tipo:

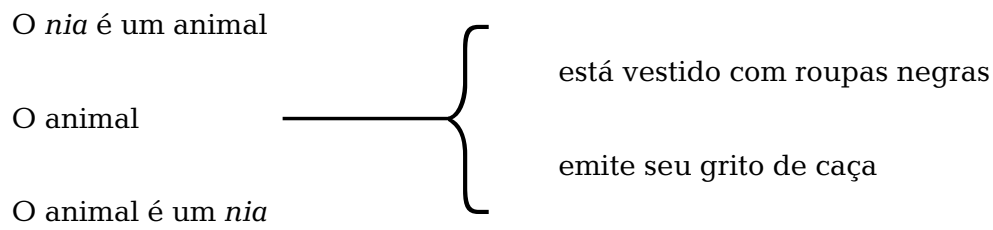

De fato, por intermédio da exibição de uma aparência diferente do animal (sempre descrito no texto de acordo com essa fórmula convencional), o texto fornece a prova, do ponto de vista indígena, da transformação do espírito em um animal. As roupas negras que ocultam a pele do porco-do-mato só podem referir-se nesse contexto à presença noturna, invisível, do jaguar celeste - o maior de todos os espíritos malignos, e o único capaz de se transformar em qualquer tipo de criatura. A introdução da idéia de que roupas negras envolvem o corpo do animal torna-se, então, um meio de expressar a um só tempo o 
caráter noturno, invisível, do espírito e sua encarnação visível como uma criatura da floresta.

Quando o espírito do animal deixa de ser reconhecível pelo seu aspecto visível, sua presença será revelada inequivocamente pela referência ao seu grito de caça no canto xamânico. E essa referência a uma presença oculta revelada pela sua imagem acústica reproduz fielmente o modo dual da aparência do jaguar celeste: seja como uma imagem noturna mergulhada na escuridão, ou como uma presença invisível que apenas a alucinação auditiva do grito do animal torna perceptível para o caçador na floresta.

Novamente aqui, a presença simultânea de um espírito invisível e de uma aparência animal que se esconde da luz do dia define a natureza ontológica do espírito. Do mesmo modo que Balsa, o Vidente, os nia revelam sua natureza no próprio ato de transformarem-se. A imagem do espírito está situada lá (distante no espaço cosmológico), mas outro signo da sua presença, sua voz, será sempre percebido aqui, perto da aldeia humana. Vimos que, nas cosmologias ameríndias, o estabelecimento de distinções entre diferentes territórios do universo (a Terra, o Mar, o Céu, o Mundo Subterrâneo) torna-se um meio de delinear diferentes categorias ontológicas; um ser é definido pelo território ao qual pertence. Podemos ver agora que um espírito pode ser definido como um ser que possui muitas naturezas, pertencendo, portanto, a diversos territórios cosmológicos. A estrutura ambígua do espaço sobrenatural (no qual certas coisas podem estar simultaneamente aqui e lá) torna-se então um meio de caracterizar a natureza múltipla dos seres sobrenaturais.

Na tradição xamânica kuna a definição do sobrenatural está articulada com a idéia da conjunção de traços contraditórios: um animal, uma árvore e até mesmo um ser humano só podem se tornar sobrenaturais se também incorporam a natureza de outros seres. Sua contradição interna (e o fluxo de metamorfoses articuladas a ela) é expressa em termos espaciais como a presença simultânea do mesmo ser em diferentes lugares da paisagem. De acordo com essa perspectiva um rio não apenas pode desembocar no corpo de uma mulher que sofre, mas uma Árvore Balsa e um Porco-do-Mato podem ser considerados - nas paisagens sobrenaturais, nos sonhos, e depois da morte - invisíveis "aqui" e brilhando como ouro "lá". Do mesmo modo, o Espírito do Branco pode ser considerado simultaneamente planta e animal, bom e mau, espírito patogênico e curandeiro mágico. 


\section{Conclusões}

Como em muitas outras sociedades ameríndias, a tradição xamânica kuna escolheu a dimensão sobrenatural (com a sua relação com a representação do sofrimento) para representar crises sociais e traumas coletivos. É lá (naquele mundo que é concebido simultaneamente como uma paisagem invisível e como um corpo) que os inimigos verdadeiros dos Índios tornam-se também novos seres invisíveis. A recordação ritual do passado implica paradoxalmente a renovação do sobrenatural. Entretanto, a representação do Espírito do Branco (ou melhor, a metamorfose ritual dos Brancos em Espíritos), com sua série de conotações opostas (assassino/ assassinado; humano/animal; amigo/inimigo...), segue exatamente o mesmo padrão estabelecido para a representação de qualquer espírito. A transformação ritual de um inimigo em um espírito, longe de ser redutível à simples "magia simpática" (Taussig 1993), marca justamente um passo além na mesma lógica de condensação. Assim, essas representações, quando encaradas do ponto de vista indígena, não são ambíguas ou "confusas" (como aparecem inevitavelmente do ponto de vista ocidental), elas são negativas de uma forma complexa.

À medida que partilham a mesma complexidade (a conjunção de traços contraditórios) que define qualquer ser sobrenatural kuna, essas representações carregam indicações "realistas" no que diz respeito à verdadeira natureza dos seus inimigos Brancos. Longe de serem sintomas de uma perda de identidade (ou de uma iminente submissão a valores "modernos", estrangeiros), essas representações indicam que a memória social desses grupos ainda é, a despeito das aparências, muito viva. Ambigüidade ou, mais precisamente, a capacidade de representar crises sociais e individuais através do paradoxo - um termo por meio do qual definimos a coexistência de aspectos conflitantes e contrários da mesma situação - é uma força, não uma fraqueza das imagens rituais kuna.

De um ponto de vista mais geral, esses fatos sugerem que existem pelo menos dois modos de construir memórias sociais: um opera através da narração (e renovação contínua) de uma série de histórias; o outro, sempre vinculado à elaboração da memória ritual, tende a criar um número relativamente estável de imagens cada vez mais complexas, cada vez mais "carregadas" de significados e cada vez mais persistentes ao longo do tempo. Dois aspectos desse último modo de produzir memórias emergiram aqui. Antes de mais nada, essas imagens são sempre construídas em um contexto ritual. Elas são vistas, de uma perspectiva warburgiana, 
como etapas em uma seqüência de representações rituais: as estatuetas "Brancas" kuna são impensáveis sem os cantos e sem a cosmologia elaborada que os cantos evocam na tradição kuna. Em segundo lugar, devemos sublinhar que a representação dos "Homens Brancos" é sempre percebida como um dos aspectos e, poder-se-ia até dizer, um aspecto contingente, do mundo sobrenatural kuna. Os espíritos tornam-se "Brancos" entre outras coisas. Ser Branco é apenas uma das transformações possíveis, e os espíritos fazem isso mantendo sua essência fundamental, que é estarem continuamente engajados em uma metamorfose orientada ritualmente.

Resta pouca dúvida de que a emergência dos Espíritos do Branco nas práticas xamânicas kuna refere-se a uma longa série de conflitos violentos em que se enfrentaram Índios e os agressores vindos do Ocidente. Entretanto, uma vez inseridas em uma tradição ritual, as histórias do passado desfazem-se e se condensam em imagens complexas. Dois processos parecem operar na elaboração dessas imagens: um tende a obliterar o fato externo para inseri-lo em um arcabouço conceitual indígena - a cosmologia do mundo sobrenatural; o outro segue um caminho simétrico: usa as ambigüidades da cosmologia para representar aspectos proeminentes dos recém-chegados. O resultado é um elaborado (e ritualmente poderoso) "engrama" da tradição ritual, e torna-se uma parte significante da memória social.

A maneira pela qual a memória ambígua do Branco se estabelece na tradição kuna revela, então, uma dinâmica similar à que foi proposta por Freud a respeito da elaboração psicológica do trauma. Essas imagens operam como traços mnêmicos; elas evocam o passado por meio da exploração xamânica do sofrimento, mas elas o tornam presente sem representá-lo através de uma narrativa. M. Roth (1994) mostrou quão fundamental foi, para os primeiros trabalhos de Freud, o estudo dos diversos modos pelos quais o passado pode causar dor no presente. Nesse sentido, o próprio sintoma é concebido por Freud como um símbolo do passado. O estudo de algumas imagens cruciais da tradição kuna mostra como um símbolo complexo, enraizado na representação de uma experiência traumática, pode operar como um traço mnêmico de um passado que sempre retorna.

Uma imagem do passado relembrada ritualmente, que segue estritamente a definição de trauma: uma reminiscência que, ao mesmo tempo que se recusa a emergir completamente à consciência, se recusa igualmente a seguir seu caminho e cair no esquecimento. As imagens dos homens e mulheres Brancos, com seus grandes chapéus, colares, camise- 
tas pintadas e calças, esculpidas grosseiramente em pau-de-balsa pelos xamãs kuna, uma vez recolocadas na paisagem sobrenatural que as situa, simultaneamente, "aqui no corpo" e "lá além do horizonte", revelam essa tensão melhor do que qualquer história.

Recebido em 14 de junho de 1999

Tradução: Kátia Maria Pereira de Almeida

Carlo Severi é membro do Laboratoire d'Anthropologie Sociale do Collège de France. Realizou pesquisa de campo entre os Kuna do Panamá e publicou La Memoria Rituale (1993), sobre o xamanismo kuna. Com Michael Houseman escreveu um estudo teórico da ação ritual, Naven, ou le Doneer à Voir (1994), cuja segunda edição, em inglês, chama-se Naven, or the Other Self. A Relational Approach to Ritual Action (1998).

\section{Notas}

1 Ricoeur, por exemplo, escreve: “o tempo não se torna humano senão na medida em que é articulado sob um modo narrativo, e o relato não atinge sua significação primeira, senão quando ele se torna uma condição da existência temporal" (1983:105).

2 Uma das objeções mais comuns em relação ao estudo das imagens nesse contexto diz respeito ao que poderia ser denominado de pobreza semiótica peculiar à linguagem icônica. "Nunca confunda um desenho com um texto", prevenia apropriadamente Gombrich no seu famoso livro The Sense of Order (1979): o modo de produzir significado de um desenho - argumentava o grande historiador da arte - é totalmente diferente daquele do signo. Um desenho deve ser apreciado livremente de modo estético, um signo deve ser decifrado a partir de regras implícitas (Gombrich 1979:362). Como conseqüência, a comunicação através de signos tende a ser mais fácil e precisa, enquanto a comunicação por imagens é difícil, sempre arbitrária, inevitavelmente vaga (Severi 1997). Uma das razões invocadas para essa imprecisão é a impossibilidade de as imagens expressarem um aspecto essencial da linguagem: a negação. Se nenhuma negatividade pode ser expressa em termos icônicos, então as imagens devem ser consideradas logicamente muito fracas para sustentarem qualquer memória social. 
3 Os trabalhos de Georges Devereux e Gregory Bateson são certamente, por diferentes razões, as tentativas mais competentes e bem-sucedidas de desenvolver uma abordagem do estudo dos fatos sociais capaz de enriquecer as idéias de Freud.

4 Ver, p. ex., Chapin (1983:93), que trabalhou com especialistas kuna entre 1971 e 1976: "os nuchucana (figuras ou estatuetas rituais esculpidas em pau-debalsa) medem normalmente um pé de altura e são esculpidos quase invariavelmente para se assemelharem a não-índios".

5 Os estudos de Stoller dedicados ao movimento Hauka $(1984 ; 1989)$ são memoráveis e intelectualmente instigantes. Os membros desse movimento, que começou entre os Songhay na Nigéria francesa e em Gana britânica por volta de 1925, dançavam e ficavam possuídos pelos espíritos dos administradores coloniais. A reação das autoridades coloniais consistia em reprimir o movimento e aprisionar tantos membros do Hauka quantos fosse possível capturar.

6 Os índios Kuna vivem hoje no Arquipélago de San Blas, no Panamá. A nação kuna conta com cerca de 27 mil a 30 mil pessoas, que falam uma língua tradicional pertencente à família chibcha (Holmer 1947; 1951). Um pequeno grupo kuna, que ainda rejeita qualquer contato com o homem branco, vive na região Chucunaque da Floresta Dorien, próxima à fronteira com a Colômbia. Os Kuna são basicamente agricultores tropicais. Em seu breve levantamento histórico, Stout (1947) especula que a sociedade kuna, uma das primeiras a entrar em contato com os homens brancos depois da descoberta do continente americano, era "rigidamente estratificada, e dividida em quatro classes: líderes, nobres, cidadãos e escravos". Hoje, o poder político é controlado pela onmakket, uma assembléia que reúne todos os homens adultos da aldeia, apoiada por um número variável de líderes eleitos (sailakan). O sistema de parentesco kuna é bilinear, uxorilocal e baseado em uma exogamia estrita (Howe 1976; 1986). Um levantamento preliminar da bibliografia sobre os kuna pode ser encontrado em Kramer (1970); Howe, Sherzer e Chapin (1980); Sherzer (1983; 1990); Severi (1993).

7 Um estudo comparativo dessa representação do Branco entre os índios americanos ainda está por ser feito. Os trabalhos de Basso (1966) e Erikson (1996) constituem dois exemplos interessantes.

8 Uma primeira versão desta seção foi apresentada no congresso sobre "Paisagens Sobrenaturais", realizado na Universidade de Heidelberg, em novembro de 1995.

9 A respeito deste canto, dedicado à terapia daquilo que os Kuna chamam "locura", ou doença mental, ver Holmer e Wassen (1958); Severi (1982; 1987; 1993).

${ }^{10}$ A respeito desses comentários, ver Severi (1982:33-34).

11 A respeito dos videntes e xamãs na tradição kuna, ver Severi (1987). 
12 O nome deste espírito em kuna é Nele Ukkurwar, que quer dizer literalmente Tronco Leve, o Vidente. Ele é sempre referido no texto pelo termo kilu ("tio", literalmente) que se aplica a pessoas adultas e respeitáveis. O termo Nele ("vidente") designa: 1. os heróis culturais da mitologia kuna; 2. o adivinho a quem é atribuída a tarefa de estabelecer um diagnóstico; 3. os espíritos auxiliares do xamã-cantor, representados pelas estatuetas de madeira durante o ritual de recitação dos cantos. A respeito desses tópicos, ver Severi (1987).

13 O significado literal da palavra kuna kalu, traduzida aqui por "aldeia" (como sói ocorrer na literatura antropológica dedicada aos Kuna), é "cercado", "cerca". A cerca da cabana tradicional kuna também é chamada de kalu. A respeito desses temas, ver, p. ex., Herrera, Cardale e de Schrimpff (1974).

14 Uma versão deste canto, em kuna e espanhol, foi publicada em Holmer e Wassen (1963).

15 "Depois que os pranteadores se vão, o último ato dos coveiros é prender uma corda a uma das estacas da rede e esticá-la até o outro lado do rio; a primeira pessoa que subir ou descer o rio deve cortá-la" (Stout 1947:40). Esse rito é repetido por três dias consecutivos após a morte, além do nono dia do primeiro mês e do trigésimo dia dos próximos seis meses. Prestan (1975:105) acrescenta a essa descrição que "um número de disparos" é feito com uma arma, "de modo a avisar as pessoas que o ritual está terminado". Prestan também menciona dois aspectos desse ritual que eu não estou analisando aqui: a partilha da comida com as pessoas mortas e a oferenda de sementes de cacau aos espíritos (Prestan 1975:106).

${ }^{16}$ Este canto foi publicado originalmente, em uma versão incompleta, em Holmer e Wassen (1947), e então em uma versão nova e completa em Holmer e Wassen (1953).

${ }^{17}$ Sobre os conceitos kuna relativos ao princípio vital (purpa, significando "duplo", nika, "força física", kurkin, "força espiritual ou influência"), ver Severi (1987; 1993).

18 Aqui eu corrijo a tradução de Holmer e Wassen (o "barco do estrangeiro"). A palavra kuna waka tal como usada aqui se aplica apenas aos Brancos.

19 Outra expressão para designar o sexo feminino.

${ }^{20}$ Esse significado é confirmado também pelo simbolismo usado nos rituais de iniciação femininos, nos quais uma "corda de algodão" designa um cordão umbilical (Prestan 1975:52). Em outro canto, aquele narrando as origens de Tronco Leve, os "fios" são sempre identificados com a matriz genital da Primeira Mãe (Velasquez 1992:702 e ss.).

${ }^{21}$ O significado ritual das folhas de banana selvagem é bem ilustrado por Chapin (1983:401-403). 
${ }^{22}$ Stout escreve, entretanto, que o céu kuna tem também oito camadas: "Os Kuna concebem o mundo como um plano terrestre no qual as pessoas vivem, com um céu de oito camadas invisíveis acima e um submundo de oito camadas abaixo [...]" (Stout 1947:40).

${ }^{23}$ Lovejoy (1936) reconstruiu as origens e a evolução desse conceito no seu clássico A Grande Cadeia do Ser. Para um debate contemporâneo sobre essa questão, ver, p. ex., Premack e Premack (1994). Uma primeira discussão desse assunto pode ser encontrada em Severi (1982).

${ }^{24}$ Se essa cultura é vista como a mesma cultura dos humanos, uma espécie de imagem refletida projetada nos reinos vegetal e animal pela sociedade (como Viveiros de Castro 1996 argumentaria), ou se, ao contrário, a sociedade concebe o "mundo natural" como uma cultura diferente, é, normalmente, uma questão de variação cultural. O caso kuna corresponde mais a esta última hipótese.

${ }^{25}$ Contrariando o que Holmer e Wassen escreveram, não existe nenhum modo de traduzir esse texto fazendo referência a uma "doença obscura" (Holmer e Wassen 1963:27, nota 1). O texto kuna e, a saber, a expressão nekulu ekarkwenasatti muchuppi não deixam dúvida a respeito do significado dessa passagem. Nekulu sempre significa "sob a terra", e a mesma expressão kalu ekarkwenai aparece no Canto do Demônio com o mesmo significado: "a aldeia está coberta de nuvens" (Gomez e Severi 1983:152-153).

${ }^{26}$ Toila em kuna; Lurocalis semitorquatus na denominação científica [bacurau é uma designação comum para pássaros caprimulgídeos. A espécie referida é conhecida em português como tuju. N.T.].

27 "Trabalhar", neste caso, significa "manter relações sexuais com".

${ }^{28}$ Os Nuchumar são os espíritos auxiliares do xamã kuna, que representam geralmente (embora nem sempre) árvores ou espíritos vegetais.

${ }^{29}$ Eu coletei este texto, traduzido aqui do kuna, durante minha expedição de 1982 à aldeia de Mulatupu. 


\section{Referências bibliográficas}

BASSO, Keith. 1966. "The Gift of Changing Woman". Bureau of American Indians Bulletin, 196(76).

.1979. Portraits of the White Man. Linguistic Plays and Cultural Symbols among the Western Apache. Cambridge, Mass.: Cambridge University Press.

BRUNER, Jerome. 1990. Acts of Meaning. Cambridge: Harvard University Press.

CHAPIN, M. 1983. Curing among the San Blas Kuna. Ph.D. Dissertation, University of Arizona.

ERIKSON, Philippe. 1996. La Griffe des Aiëux. Marquages Corporels chez les Matis d'Amazonie Brésilienne. Paris: Peteers.

FREUD, Sigmund. 1965[1917]. A General Introduction to Psychoanalysis. New York: Washington Square Press.

GOMBRICH, E. 1979. The Sense of Order. A Study in the Psichology of Decorative Art. Oxford: Phaidon Press.

GOMEZ, Elsa e SEVERI, Carlo. 1983. "Nia Ikala, los Pueblos del Camino de la Locura" (Texto Kuna y Traducción Española"). Amerindia: Revue d'Ethnolinguistique Amérindienne, 8:129-179.

HERRERA， L., CARDALE, M. e DE SCHRIMPFF. 1974. "Mitología Kuna: Los Kalu". Revista Colombiana de Antropología, XVII:201-248.

HOLMER, Nils 1947. A Critical and Comparative Grammar of the Kuna Language. Göteborg. . 1951. Kuna Chrestomathy. Etnologiska Studier. Göteborg: Etnografiska Museet. e WASSEN, Henry. 1947. Mu Ikala or the Way of Mu. A Cura Shamanistic Chant. Etnologiska Studier.
Göteborg: Etnografiska Museet. . 1953. The Complete Mu Ikala. Etnologiska Studier 21. Göteborg: Etnografiska Museet. .1958. Nia Ikala, Canto Magico para Curar la Locura. Etnologiska Studier 23. Göteborg: Etnografiska Museet.

. 1963. Dos Cantos Chamanísticos de los Indios Kuna. Göteborg: Etnografiska Museet.

HOWE, James. 1976. “Communal Land Tenure and the Origin Descent Groups among the San BlasKuna". In: M. Helms e F. O. Loveland (eds.), Frontier Adaptions in Lower Central America. Philadelphia: ISHI.

_. 1986. The Kuna Gathering. Austin: Texas University Press.

.1997. "The Kuna and the World: Five Centuries of Struggle". In: M. L. Salvador (ed.), The Art of Being Kuna. Layers of Meaning among the Kuna of Panama. Catalog of Exhibition, The Fowler Museum of Cultural History. Los Angeles: University of California. , SHERZER, Joel e CHAPIN, M. 1980. Cantos y Oraciones del Congreso Kuna. Panama: Editorial Universitaria.

KANTULE, Perez e NORDENSKIÖLD, Erland. 1938. "La Creación de las Tortugas". Comparative Ethnographical Studies, 10:388-392.

KRAMER, Fritz 1970. Literature among the Kuna Indians. Göteborg: Etnografiska Museet.

LOVEJOY, Arthur O. 1936. The Great Chain of Being. Cambridge, Mass.: Harvard University Press.

MÉTRAUX, Alfred. 1958. Le Vaudou Haitien. Paris: Gallimard.

NORDENSKIÖLD, Erland. 1928. "PictureWritings and Other Documents". 
Comparative Ethnographical Studies, I e II. Göteborg: Ethnological Museum.

. 1938. "An Historical and Ethnographical Survey of the Kuna Indians". Comparative Ethnographical Studies, X. Göteborg: Ethnological Museum.

PREMACK, David e PREMACK, Ann. 1994. "Why Animals Have neither Culture nor History". In: T. Ingold (ed.), Companion Encyclopedia of Anthropology. London: Routledge. pp. 350-365.

PRESTAN, A. 1975. El Uso de la Chicha y la Sociedad Kuna. México: Instituto Indigenista Interamericano.

RICOEUR, Paul. 1983. Temps et Récit. L'Intrigue et le Récit Histórique. Paris: Le Seuil.

_ .1985. Temps et Récit. Le Temps Raconté. Paris: Le Seuil.

ROTH, Michael. 1994. "Freud's Use and Abuse of the Past". In: M. Roth (ed.), Rediscovering History: Culture, Politics, and the Psyche. Stanford: Stanford University Press.

SALVADOR, Mari Lyn (ed.). 1997. The Art of Being Kuna. Layers of Meaning among the Kuna Indians. Los Angeles: UCLA/Museum of Cultural History.

SEVERI, Carlo. 1981. "Image d'Etranger". Res - Anthropology and Aesthetics, 1:88-94.

. 1982. "Le Chemin des Métamorphoses: Un Modèle de Connaissance de la Folie dans un Chant Chamanistique Kuna". Res - Anthropology and Aesthetics, 3: 32-67.

_ . 1987. "The Invisible Path - On the Ritual Representation of Suffering in Kuna Shamanistic Tradition". Res - Anthropology and Aesthetics, 14: 66-86.

.1993. La Memoria Rituale: Follia e Immagine del Bianco in una Tra- dizione Sciamanica Amerindiana. Firenze/Roma: La Nuova Italia. (Tradução espanhola de R. Pochtar: La Memoria Ritual. Locura e Imagen del Blanco en una Tradición Chamánica Amerindia, Quito, Ediciones Abya Yala, 1996.)

1997. "Kuna Picture Writing. A Study in Iconography and Memory". In: M. L. Salvador (ed.), The Art of Being Kuna. Layers of Meaning among the Kuna Indians. Los Angeles: UCLA/Museum of Cultural History. pp. 245-270.

SHERZER, Joel. 1983. Kuna Ways of Speaking: An Ethnographic Perspective. Austin: University of Texas Press. . 1990. Verbal Art in San Blas. Cambridge: Cambridge University Press. STOlleR, Paul. 1984. "Horrific Comedy: Cultural Resistance and the Hauka Movement in Niger". Ethos, 12(2): 165-188.

.1989. Fusion of the Worlds: An Ethnography of Possession among the Songhay of Niger. Chicago: Chicago University Press.

STOUT, David. 1947. San Blas Kuna Acculturation. New York: Viking Fund Publications in Anthropology.

TAUSSIG, Michael. 1993. Mimesis and Alterity: A Particular History of the Senses. London: Routledge.

VElASQUEZ, R. 1992. El Canto Chamánico de los Indígenas Kuna de Panama. Ph.D. Dissertation, Universidad Central de Venezuela, Caracas.

VIVEIROS DE CASTRO, Eduardo. 1996. "Os Pronomes Cosmológicos e o Perspectivismo Ameríndio". Mana, 2(2):115-144.

WARBURG, Aby. 1932. Gesammelte Schriften. Leipzig: B. G. Terbner.

WHITE, Hayden. 1973. Metahistory, the Historical Imagination in the XIXth Century Europe. Baltimore: The Johns Hopkins University Press. 


\section{Resumo}

Tomando como foco uma análise da iconografia ritual kuna, este artigo procura delinear uma teoria da memória social baseando-se tanto em imagens quanto em narrativas. A emergência do Espírito do Branco na iconografia xamânica kuna refere-se à longa série de conflitos violentos entre índios e brancos que marcam a história desse povo. Todavia, uma vez inseridas na tradição ritual, essas histórias do passado se fundem e condensam em imagens complexas. Dois processos parecem operantes na elaboração dessas imagens: um tende a obliterar o fato externo para inseri-lo em um quadro conceitual indígena (a cosmologia do mundo sobrenatural); o outro emprega as ambigüidades da cosmologia para representar um aspecto saliente dos recém-chegados. O resultado é um elaborado (e ritualmente poderoso) "engrama" da tradição ritual, que passa a constituir uma parte significativa da memória social.

\section{Abstract}

Focussing on an analysis of the Kuna ritual iconography, this paper sets out to outline a theory of social memory based on images as well as on stories. The emergence of White Spirits in kuna shamanistic iconography refers to the long series of violent conflicts that have opposed Indians and Whites. However, once inserted in ritual tradition, stories of the past collapse, and condense in complex images. Two processes seem to be at work in the elaboration of these images: one tends to obliterate the external fact to insert it in an indigenous conceptual frame (the cosmology of the supernatural world); the other employs the ambiguities of cosmology to represent a salient aspect of the newcomers. The result is an elaborate (and ritually powerful) "engram" of ritual tradition, and becomes a significant part of social memory. 